address Sir Donald MacAlister praised the "admirable services rendered by women doctors," noted the "large augmentation in the number of women students" (table II), and commended the appeal to "all women practitioners who are physically fit for such duty." Four years later, in 1920, he warned them that their "services were less in demand." They would have difficulty "in obtaining suitable opportunity" and "disappointments may be encountered." Time and circumstances had changed attitudes, but it is interesting that at the beginning of the second world war the GMC was able to ensure that medical students were not called up

\begin{tabular}{lccc}
\multicolumn{4}{l}{ TABLE II Student census 1916} \\
\hline Year of study & Men & Women & Total \\
\hline First & 1422 & 636 & 2058 \\
Second & 783 & 295 & 1078 \\
Third & 519 & 163 & 682 \\
Fourth & 1078 & 145 & 1223 \\
Final & 922 & 140 & 1062 \\
\hline
\end{tabular}

The fall in the number of men students in their second and third years was due to the exodus to the armed forces. This also caused the intentional increase in the admission of women students in 1916.

provided that they made satisfactory progress, and after the war the problem was less acute.

In the 'twenties five London teaching hospitals closed to women and though London University Senate appointed a committee to look into this and Lady Rhondda, the industrialist, organised a protest group it was all to no avail and the GMC seems to have taken no interest. ${ }^{8}$

Universal coeducation in medical schools had to await acceptance of the Goodenough report 1944, which made Exchequer grants to universities conditional on schools admitting a reasonable proportion of women students. With the passing of the Sex
Discrimination Act 1975 admissions of women rose to around a half.

For some time the GMC had had difficulty in balancing its budget. It had appealed to parliament through the Privy Council and eventually the Medical Act 1969 gave permission to introduce an annual retention fee. According to the 1970 minutes, the BMA council had decided not to oppose this, but such a decision made without the assent of the representative body proved to be unconstitutional. Ultimately, the latter agreed that it "would not oppose the fee, provided the GMC agreed to certain propositions concerning composition and functions of the GMC." This led eventually to the Merrison report and the Medical Act 1978, which among other things stipulated that there should be a majority of elected members on the council. The outcome of this has meant that there are now five elected women on the council in addition to the three nominated by the Privy Council, and one by Southampton University. Before the Act only nine women had ever served on the council over the past 30 years and the maximum at any time had been three. Who and what they were is another story, but they were important women in their time.

I should like to thani Sir John Walton and the members of staff of the General Medical Council for their help; the Medical Archive Centre, Edinburgh University, which allowed me to study its GMC records; and the present council members of the Medical Women's Federation who encouraged me to write this paper.

\section{References}

1 Masefield M. Seven against Edinburgh. London: Heinemann, 1951 Raikes E. Dorothea Beale of Cheltenham. London: Constable, 1908.

Fulford R. Votes for women. London: Fa

Paget S. Memoirs and leters of Sir fames Paget, edited by Stephen Paget, one of his sons. London: Longman, 1901.

5 Chambers P. A doctor alone. London: Bodley Head, 1956.

7 Christison Family. The life of Sir Robert Christison. By his sons. Edinburgh: William Blackwood

8 Lang EM. British women in the twentieth century. London: T Werner Laurie, 1929.

\title{
A matter of no importance
}

\section{A PYKE}

\section{Introduction}

I have a proof reader's mind. As I read I repeatedly stumble over trivial blemishes of fact that have as little to do with the theme of a book as uneven paving has with the direction of a path. As a result I am always losing the thread of the story. It is a great sadness to me.

John Malins has a similar problem: "I have ever been a desultory and inattentive reader of text books," he wrote, "always remembering what is unimportant at the expense of the big message. My only recollection of Bailey and Love's text book of surgery are the watercress vendors of Paris and the bust of Napoleon lodged in the rectum."

So too had Ivy Litvinov.' She, you will remember, was the English girl who soon after the first world war married Maxim Litvinov, the Russian revolutionary, then living in London who later became foreign commissar of the Soviet Union. It was an adventurous thing for him to marry an English woman and even more so for her to marry a Russian exile with no apparent future. On his wedding day Litvinov, in his uncertain English, asked his bride,

King's College Hospital, London SE5 9RS

D A PYKE, MD, FRCP, physician
"Don't you feel we have burned our ships?" "Boats," she corrected him.

I can now turn my impediment to advantage by reporting literary errors that I have noticed over the years. Not that mistakes are necessarily a bad thing-Wilhelm Feldberg quotes Sir Joseph Barcroft as saying that he got a lectureship at Cambridge for a particular piece of work and later a fellowship for disproving it.

\section{Material}

The errors in the present study come from: Macfarlane's life of Florey, ${ }^{2}$ Tuchman's Bible and Sword ${ }^{3}$ various writings of Damon Runyon, ${ }^{45}$ Gilbert's study of Winston Churchill in middle life, ${ }^{6}$ Lord Macaulay's essay on Warren Hastings, ${ }^{7}$ Twelfth Night, and three plays by Oscar Wilde. ${ }^{8}$

They are errors or inconsistencies of fact; none affects the story in which it is embedded - and none is of the least importance. They concern time and tense, distance and date, name and identity. All are reported here for the first time, or so I think. 
Statistics

None.

\section{Results}

DATE

A typical error occurs in Gwyn Macfarlane's marvellous biography of Florey in which he speaks of the second world war beginning on 24 August 1939. Noticing this mistake-the war began on 1 or 3 September, according to whether you were Polish or Anglo-French -and having once sat admiringly at Macfarlane's feet I wrote to him. It was some months after the book was published (having this proof reader's complaint I am a slow reader). Macfarlane had noticed the mistake himself during proof reading and asked Oxford University Press to correct it. It was too late, they said, but "don't worry, no one will notice it." And no one had.

Another and surprising error of date comes from the American historian, Barbara Tuchman, in her splendid book Bible and Sword when she places the Stuart Restoration in 1666; a printer's error perhaps, but in my edition it had survived for 26 years. It cannot have been a printer's error which led her to describe the opening of the Suez Canal thus: "By 1869 de Lesseps had triumphed. The Suez Canal was a reality. On November 17, 1869 the Imperial yacht, with the Empress Eugénie on board, led the opening procession through the locks." 3

There are no locks on the Suez Canal.

\section{NUMBER}

I suppose numbers seem large or small according to your point of view. A slightly overweight friend of mine complained that he weighed 85 million milligrams. To Churchill, who habitually thought of military matters, the figure of a hundred thousand must have seemed large. When in 1932 he had an alimentary haemorrhage and lost "about two-fifths of my blood" he proclaimed in a letter to Stanley Baldwin written when he was convalescing that "I am recovering, and recruiting red corpuscles at about 100000 a day." At that rate, and assuming that he was referring to the increase in his red cell count not to their absolute production in which case his marrow would have been aplastic, his haemoglobin would not have returned to normal for about a quarter of a million years. Fortunately for us all he did better than that.

Perhaps he had inherited some of his father's incomprehension of numbers-after Lord Randolph had ceased to be Chancellor of the Exchequer he said, "I never could make out what those damned dots meant."

\section{DISTANCE}

Macaulay is well known for the bigotry of his opinions, particularly about people. If they in any way incurred his displeasure they were damned. William Penn, the Quaker and founder of Pennsylvania, was condemned for the activities of another Penn, but when this case of mistaken identity was pointed out to him Macaulay refused to correct it. But he makes an error of a different sort in his article on Warren Hastings; he twice refers to the distance between London and Calcutta as being 15000 miles. $^{8}$

\section{TENSE}

I now come to Damon Runyon, the author of Guys and Dolls and other marvellous short stories about New York characters which I devoured in the 1930s when they were first published over here. ${ }^{45}$ The stories are written entirely, or almost entirely, in the present tense. I have discovered two exceptions. In A Very Honourable Guy the storyteller says "all the years I am around this town, I always try to keep in with the high shots and guys who carry these large coarse bank-notes with them, and I stay away from small operators and chisellers and brokers. And Feet Samuels is one of the worst brokers in this town, and has been ${ }^{\star}$ such as long as I know him."

In The Idyll of Miss Sarah Brown, the story of the show Guys and Dolls, The Sky "comes upon a little bunch of mission workers who are holding a religious meeting, such as mission workers love to do of a Sunday evening, the idea being that they may round up a few sinners here and there, although personally I always claim the mission workers come out too early to catch any sinners on this part of Broadway. At such an hour the sinners are still in bed resting up from their sinning of the night before, so they will be in good shape for more sinning a little later on." And when does he do this? On a Sunday evening when "The Sky was walking along Broadway."

That was Runyon's fault, but another error was committed by Nicholas Bentley, who illustrated the stories when they were published in Britain. The story Breach of Promise (which is explained to Harry the Horse as "when somebody promises to do something and fails to do this something, although of course we have a different name for a proposition of this nature in Brooklyn and deal with it accordingly") shows the narrator in bed. But it was Harry the Horse who was telling the story, not "I."

\section{NOMENCLATURE}

A third and graver error is the conversion in the show Guys and Dolls of Nicely Nicely Jones, a character "who dearly loves to commit eating," into Nicely Nicely Johnson. It was because of this tampering with Holy Writ that for years I refused to see the show.

\section{DID SHAKESPEARE NOD?}

In act II of Twelfth Night comes the famous sentence "I am above thee; but be not afraid of greatness: some are born great, some achieve greatness, and some have greatness thrust upon them." This is in the letter written by Maria, pretending to be Olivia, to Malvolio, Olivia's pompous and ambitious steward. Everyone knows this passage, especially those of us who are not, nor ever will be, great. It is quoted as I have written it in the Oxford Dictionary of Quotations. Yet at the end of the play, when Feste the clown is taunting Malvolio, he quotes the concluding phrase from the letter "some have greatness thrown upon them." In the printed texts this is in quotation marks making it clear, as the action does, that it is a direct quotation from the original letter not a new construction of Feste's.

Why the change? "Thrust" is the word always quoted and seems much better than "thrown." Was it a mistake of Shakespeare's or of transcription? It is inconceivable that Shakespeare should have made an error which has passed unnoticed for 380 years. Then what is the explanation?

\section{TIME AND OSCAR WILDE}

Now to the great matter-Oscar Wilde and his sense of time. My examples come from Lady Windermere's Fan, An Ideal Husband, and, above all, The Importance of Being Earnest. ${ }^{8}$

The action of Lady Windermere's Fan takes place at the end of the London season - that is, late July. Nevertheless, when the Duchess of Berwick is having tea with Lady Windermere and does not want her daughter to hear what she has to say she tells her to "go out on the terrace and look at the sunset." The sun does not set at tea time in July.

There is a similar error in act II of An Ideal Husband. Lady Chiltern greets Lord Goring, "Good afternoon Lord Goring," he replies, "Good afternoon Lady Chiltern," and they then talk of having tea. Yet a few moments later when Lord Goring greets Miss Mabel Chiltern he says "I am a little out of practice this morning" and a little later Mabel Chiltern says "I have had four wonderful adventures this morning."

$\star$ All italics are mine. 
There also seems to be a political inconsistency in this play. Sir Robert Chiltern when he committed his crime was secretary to Lord Radley at the time that the government bought the Suez Canal shares. That government was Disraeli's who was, of course, a Tory. Yet when Lady Chiltern enters in act II she has just come from a meeting of the Women's Liberal Association. Had Chiltern changed his party, which seems unlikely as he had achieved high office by the age of 40 ? Or were he and his wife in different parties, which seems equally improbable?

Finally, to the first act of The Importance of Being Earnest. The introduction says it is tea time and this is confirmed by the cucumber sandwiches and by Algernon's remark, "I believe it is customary in good society to take some slight refreshment at 5 o'clock." But when Lady Bracknell finds out that Jack Worthing had been "born, or at least bred" in a handbag she sweeps out saying, "You can hardly imagine that I and Lord Bracknell would dream of allowing our only daughter - a girl brought up with the utmost care - to marry into a cloakroom, and form an alliance with a parcel. Good morning, $\mathrm{Mr}$ Worthing!" and he replies, "Good morning."

\section{Discussion}

How did Oscar Wilde make this error? The play was originally written in four acts. In that version Lady Bracknell leaves the room without saying anything to Worthing other than, "Will you kindly open the door for me sir. You will of course understand that for the future there is to be no communication of any kind between you and Miss Fairfax." When Wilde submitted the four act version to the actor-manager Sir George Alexander he asked Wilde to cut the play to three acts. In the process the words "all communication between yourself and my daughter must cease immediately from this moment" were put into the third act. Was it perhaps at this stage that Wilde put in the farewell "Good mornings" without remembering that the setting was tea time?
A different error in the Importance is in the tape recording made by Sir John Gielgud in 1953. Worthing's age is 29 ("A very good age to be married at. I have always been of opinion that a man who desires to get married should know either everything or nothing"Lady B), but Gielgud gives it as 35 . Perhaps as he was playing the part at the age of 49 or 50 that was an appropriate adaptation.

Why has no one--actor, producer, critic, or audience-noticed the "Good morning" error in the 100 years since the play was first performed? Or have they?

Have we, as doctors, felt lenient towards someone who could write, "the doctors found out Bunbury could not live . . . so Bunbury died." Lady Bracknell: "He seems to have had great confidence in the opinion of his physicians."

\section{Conclusions}

(1) It is more agreeable to detect error in the work of others than vice versa. (2) It is possible to spend many happy hours studying trivial things, matters of no importance.

This work was done during the tenure of a part time consultantship in the National Health Service and registrarship of the Royal College of Physicians. Neither the Secretary of State nor the president of the college is responsible for any of the errors reported, omitted-or committed-here.

\section{References}

1 Carswell J. The exile: a life of Iry Litvinov. London: Faber and Faber, 1983:80. 2 Macfarlane G. Howard Florey; the making of a great scientist. Oxford: Oxford University Press, 1979:295.

3 Tuchman B. Bible and sword. London: Macmillan, 1982:123,258.

4 Runyon D. Runyon on Broadway. London: Constable, 1954:15,415.

5 Runyon D. Guvs and dolls. London: Penguin, 1956:13.

6 Gilbert M. Winston Churchill, the wilderness years. London: Macmillan, 1981:52

7 Macaulav, Lord. Critical and historical essays. London: Dent, 1974:567,587. 8 Wilde (O. Plavs. London: Penguin, 1983.

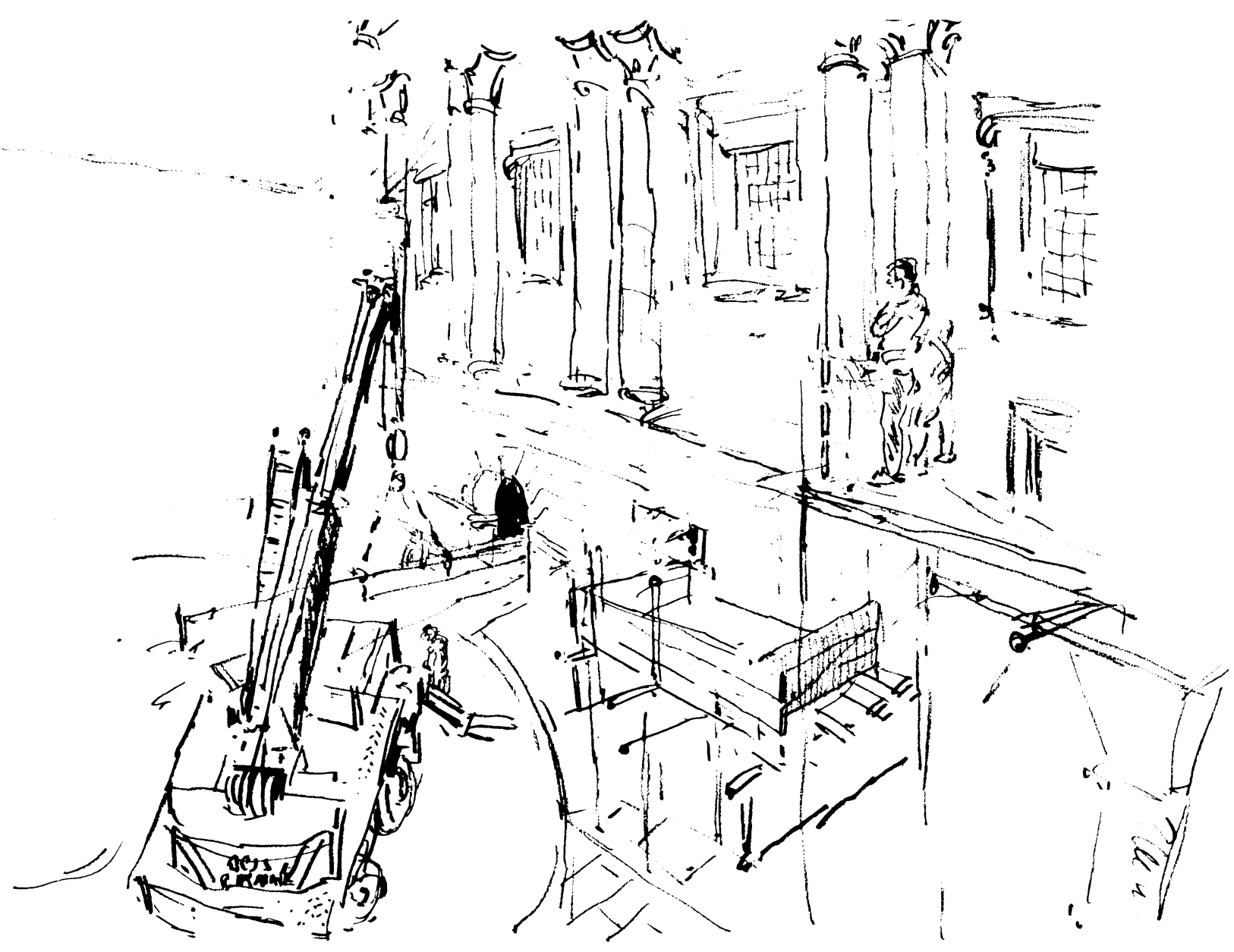

